W.J. Fokkens

J.P. van de Merwe

J.P. Braat

S.E. Overbeek

H. Hooijkaas

Short communication

\title{
The effect of intranasal and inhaled corticosteroids in healthy volunteers on the number of circulating lymphocytes and lymphocyte subsets
}

Key words: healthy volunteers; human; iatrogenic disease;

\section{Authors' affiliations:}

W.J. Fokkens, J.P. Braat, Department of Otorhinolaryngology, Erasmus University Medical Centre, Rotterdam, The Netherlands I.P. van de Merwe, H. Hooijkaas, Department of Immunology, Erasmus University Medical Centre, Rotterdam, The Netherlands S.E. Overbeek, Department of Pulmonary Diseases, Erasmus University Medical Centre, Rotterdam, The Netherlands

\section{Correspondence to:}

Dr W. J. Fokkens

Department of Otorhinolaryngology

Erasmus University Medical Centre

Dr. Molewaterplein 40

3015 GD Rotterdam

The Netherlands

Date:

Accepted for publication 13 August 1998

To cite this article:

Braat I.P., van de Merwe I.P., Hooijkaas H., Overbeek S.E. Short communication. The effect of intranasal and inhaled corticosteroids in healthy volunteers on the number of circulating lymphocytes and lymphocyte subsets.

Allergy 1999, 54, 158-164.

Copyright (C) Munksgaard 1999

ISSN 0105-4538 intrabronchial; intranasal; lymphopenia; topical

glucocorticosteroids.

Background: There has been an increasing interest in the potential systemic effects of inhaled corticosteroids.

Methods: The effect of locally inhaled corticosteroids in the nose and lung on blood lymphocytes was measured in two studies. In the first study, budesonide (BUD) (200 and $800 \mu \mathrm{g})$, fluticasone propionate (FP) (200 and $800 \mu \mathrm{g})$, and placebo were administered in the nose, and BUD $(1600 \mu \mathrm{g})$ and FP $(1500 \mu \mathrm{g})$ were inhaled into the lungs in a blinded, randomized fashion by 12 healthy volunteers. Blood samples were taken before and $4 \mathrm{~h}$ after the administration of the drug, and total lymphocyte count and different subpopulations were determined. In the second study, 15 healthy volunteers were randomized to BUD $(1600 \mu \mathrm{g})$, FP $(1600 \mu \mathrm{g})$, or placebo inhaled into the lungs. Blood samples were taken before and $4,8,24,48$, and $148 \mathrm{~h}$ (=7 days) after inhalation of the medication.

Results: Neither the nasal applications nor the inhalation of FP (1500 $\mu \mathrm{g} / 1600 \mu \mathrm{g})$ showed significant differences in total lymphocyte count or different subpopulations between baseline and $4 \mathrm{~h}$ after the administration. In both studies, a significant reduction was found in the total lymphocyte count, $B$ cells, $\mathrm{T}$ cells, and the CD4+ and the CD8+ fractions $4 \mathrm{~h}$ after application of BUD $1600 \mu \mathrm{g}$.

Conclusions: Nasal application of BUD or FP in doses up to 800 $\mu \mathrm{g}$ do not induce lymphopenia. BUD $1600 \mu \mathrm{g}$ inhalation in the lung reduces lymphocytes and their subfractions. Further studies have to be done to determine whether the results obtained in this study in healthy volunteers will also be found in patients with diseased mucosa and whether there is any correlation with adverse effects such as growth inhibition or osteoporosis. 


\section{Total lymphocytes $* 10^{9} / 1$}

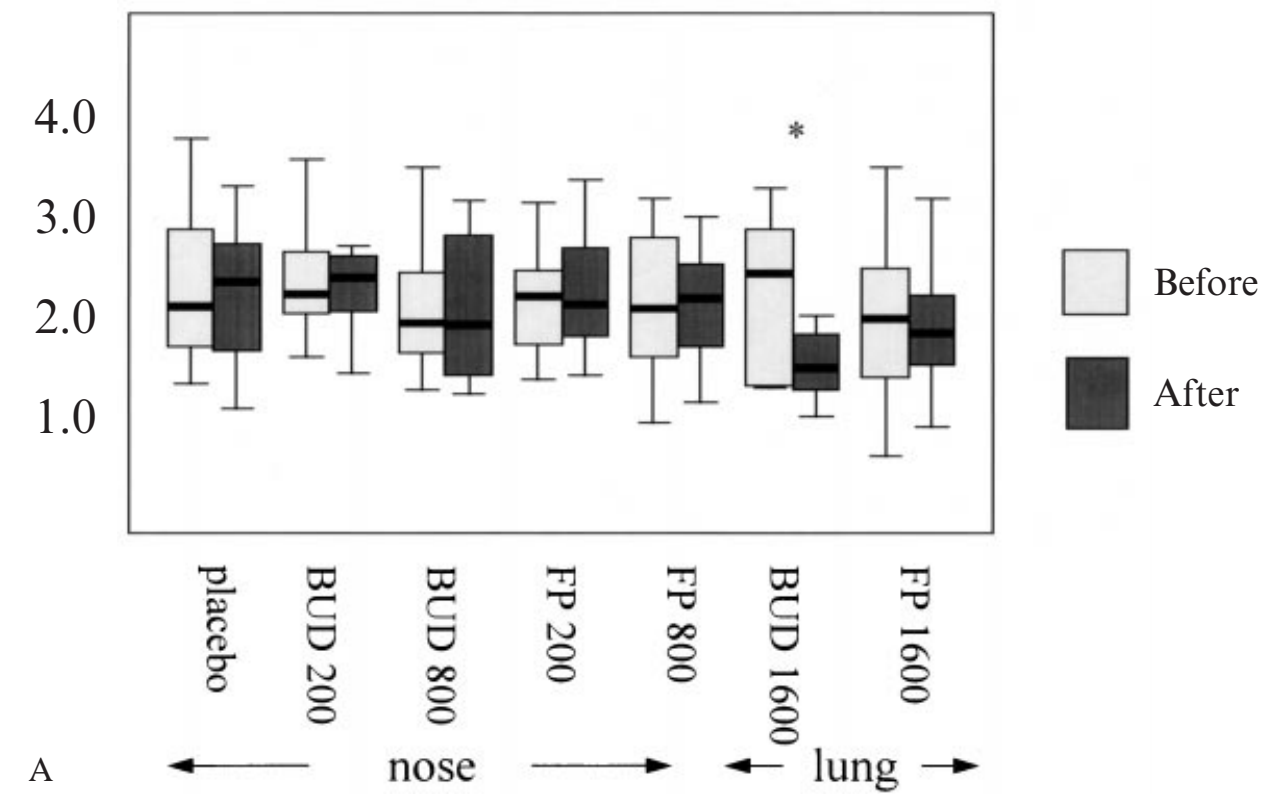

Total lymphocytes $* 10 \% / 1$

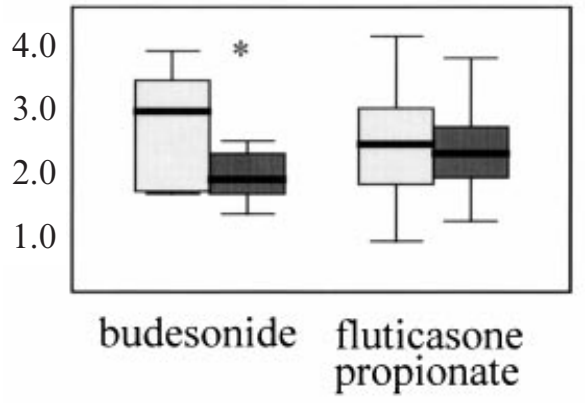

B lymphocytes * $10^{9} / 1$

CD4+ lymphocytes * $10^{9} / 1$
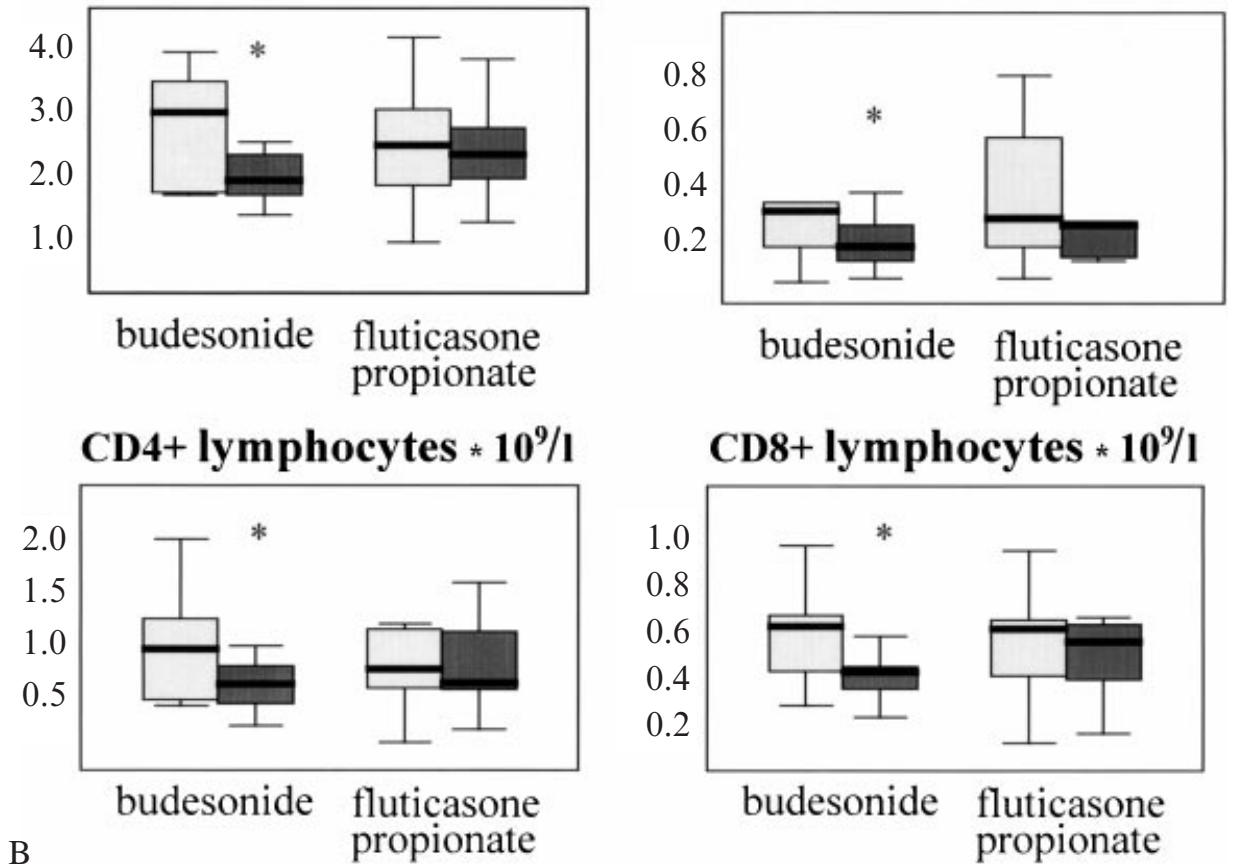

CD8+ lymphocytes $* 10 \%$

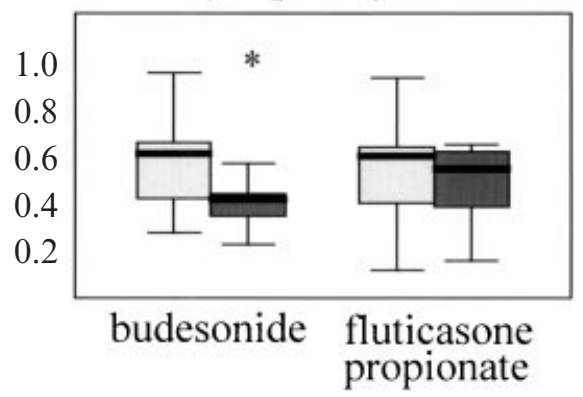

Figure 1. A) Box plots of changes in midstream total lymphocyte count after application of local corticosteroid spray ( $\mu \mathrm{g})$ in nose and lung of healthy volunteers. ${ }^{*}$ Significant reduction $(P=0.02)$. B) Changes in total number of lymphocytes, and number of $\mathrm{B}, \mathrm{CD} 4+$, and CD $8+$ lymphocytes after inhalation of budesonide $1600 \mu \mathrm{g}$ or fluticasone propionate $1500 \mu \mathrm{g}$ corticosteroid spray in lung of healthy volunteers. ${ }^{\star}$ Significant reduction $(P<0.05$. .1: before; $\mathbf{\square}$ : after.

For many years, local corticosteroid treatment has been the treatment of choice in moderate to severe rhinitis and asthma $(1-3)$. Although modern inhaled corticosteroids have all aimed at a high topical anti-inflammatory effect combined with low systemic bioavailability, it has not been possible to remove all metabolic effects and isolate desired anti-inflammatory proper- ties totally. Inhaled steroids are presently prescribed to large numbers of (young) patients, in large doses and for long periods. Hence, there has been an increasing interest in the potential systemic effects of inhaled corticosteroids. These putative effects may include bone loss; skin thinning; and metabolic, hematologic, and immunologic effects (4). Most studies 
Table 1A. Total lymphocytes and percentages of subpopulations after application of local corticosteroid spray in nose and lung

\begin{tabular}{|c|c|c|c|c|c|c|c|c|c|c|}
\hline \multirow[b]{2}{*}{ Application } & \multicolumn{2}{|c|}{$\begin{array}{l}\text { Total } \\
\text { lymphocytes }\end{array}$} & \multicolumn{2}{|c|}{$\begin{array}{l}\% \text { CD3+ } \\
\text { T cells }\end{array}$} & \multicolumn{2}{|c|}{$\begin{array}{l}\% \text { CD4+ } \\
\text { T cells }\end{array}$} & \multicolumn{2}{|c|}{$\begin{array}{l}\% \text { CD8+ } \\
\text { T cells }\end{array}$} & \multicolumn{2}{|c|}{$\%$ B cells } \\
\hline & $\begin{array}{l}\text { Before } \\
\text { median } \\
\text { (range) }\end{array}$ & $\begin{array}{l}4 \mathrm{~h} \text { after } \\
\text { median } \\
\text { (range) }\end{array}$ & $\begin{array}{l}\text { Before } \\
\text { median } \\
\text { (range) }\end{array}$ & $\begin{array}{l}4 \mathrm{~h} \text { after } \\
\text { median } \\
\text { (range) }\end{array}$ & $\begin{array}{l}\text { Before } \\
\text { median } \\
\text { (range) }\end{array}$ & $\begin{array}{l}4 \mathrm{~h} \text { after } \\
\text { median } \\
\text { (range) }\end{array}$ & $\begin{array}{l}\text { Before } \\
\text { median } \\
\text { (range) }\end{array}$ & $\begin{array}{l}4 \mathrm{~h} \text { after } \\
\text { median } \\
\text { (range) }\end{array}$ & $\begin{array}{l}\text { Before } \\
\text { median } \\
\text { range) }\end{array}$ & $\begin{array}{l}4 \mathrm{~h} \text { after } \\
\text { median } \\
\text { (range) }\end{array}$ \\
\hline Placebo & 2205 & 2445 & 74 & 74 & 45 & 47 & 33 & 32 & 12 & 13 \\
\hline$n=12$ & $(1430-3880)$ & $(1180-3400)$ & $(56-84)$ & $(64-82)$ & $(36-61)$ & (39-59) & $(20-45)$ & $(22-41)$ & $(7-20)$ & $(8-22)$ \\
\hline BANS $200 \mu \mathrm{g}$ & 2325 & 2485 & 75 & 77 & 47 & 49 & 35 & 34 & 10 & 11 \\
\hline$n=10$ & $(1700-3680)$ & $(1530-2810)$ & $(63-83)$ & $(62-80)$ & (37-61) & $(37-58)$ & $(20-47)$ & $(23-45)$ & $(5-22)$ & $(7-22)$ \\
\hline BANS $800 \mu \mathrm{g}$ & 2040 & 2025 & 76 & 73 & 40 & 44 & 35 & 34 & 12 & 11 \\
\hline$n=10$ & $(1360-3600)$ & $(1330-3270)$ & $(60-82)$ & (58-78) & $(35-58)$ & $(20-50)$ & $(21-41)$ & $(24-42)$ & $(4-23)$ & $(7-23)$ \\
\hline FPANS $200 \mu \mathrm{g}$ & 2310 & 2220 & 73 & 74 & 46 & 48 & 31 & 30 & 11 & 12 \\
\hline$n=11$ & $(1480-3850)$ & $(1510-3460)$ & $(57-80)$ & $(58-80)$ & $(30-62)$ & (39-62) & $(20-39)$ & (21-39) & $(5-19)$ & $(7-23)$ \\
\hline FPANS $800 \mu \mathrm{g}$ & 2180 & 2290 & 73 & 75 & 45 & 48 & 31 & 31 & 11 & 12 \\
\hline$n=12$ & $(1030-3290)$ & $(1250-3090)$ & $(55-87)$ & $(51-84)$ & $(36-63)$ & $(36-62)$ & $(21-47)$ & $(21-38)$ & $(6-23)$ & $(7-23)$ \\
\hline BUD $1600 \mu \mathrm{g}$ & 2530 & 1580 & 76 & 74 & 45 & 47 & 33 & 33 & 11 & 11 \\
\hline$n=9$ & $(1380-3390)$ & $(1100-3080)$ & $(65-80)$ & $(60-77)$ & $(35-63)$ & $(37-57)$ & $(22-42)$ & $(22-42)$ & $(6-21)$ & $(6-23)$ \\
\hline FP $1500 \mu \mathrm{g}$ & 2070 & 1940 & 74 & 73 & 51 & 45 & 32 & 32 & 14 & 13 \\
\hline$n=9$ & $(720-3590)$ & $(990-3290)$ & $(54-81)$ & $(55-80)$ & & & & & & \\
\hline $\begin{array}{l}\text { BANS: budesor } \\
\text { Budesonide } 16 \\
\text { after applicatic } \\
\text { lymphocyte su }\end{array}$ & $\begin{array}{l}\text { aqueous } n \\
\text { ig and flutic } \\
\text { f budesonid } \\
\text { pulations di }\end{array}$ & $\begin{array}{l}\text { spray; FPAN } \\
\text { ne propionat } \\
600 \mu \mathrm{g}(P=0.0 \\
\text { lot change af }\end{array}$ & luticaso & $\begin{array}{l}\text { propiona } \\
\text { inhaled } \\
\text { er applic }\end{array}$ & aqueous & in signi & t redu & of lym & if & $\begin{array}{l}\text { eduction } \\
\text { ttages of }\end{array}$ \\
\hline
\end{tabular}

concerning safety use tests of adrenal function to measure systemic effects, cortisol production over 1 day being the most sensitive method $(5,6)$. A review of the available studies in asthma and healthy volunteers by Pedersen \& O'Byrne indicated that, of the corticosteroids used in this study, the efficacy and the systemic potency ratio of fluticasone propionate $(\mathrm{FP})$ are usually found to be higher than budesonide (BUD) (7). There seems to be a marked individual variation in the susceptibility to systemic effects of local corticosteroids (4). However, at present, there is no simple or effective way to predict individual steroid susceptibility.

It has long been known that corticosteroids can produce lymphopenia and eosinopenia parentally (8); similar effects, although less pronounced, have been shown to occur with the use of inhaled steroids in the lung $(9,10)$. No data are available on these effects after nasal application. The effects of inhaled steroids on the cellular components of blood do not seem to be clinically significant. However, they can be used to study the amount of systemic uptake of different steroids or at different locations. Potentially, the effects on blood cells can also be used to study differences in individual susceptibility.

In the present study, the effect of locally inhaled corticosteroids in the nose and lung on blood lymphocytes was measured in healthy subjects.

\section{Material and methods}

\section{Volunteers: study 1}

Twelve healthy volunteers, median age 29 years (range 2338), five women, seven men, participated in this study. None of the volunteers were taking any medication. None of the volunteers had a history of rhinitis or asthma symptoms.

\section{Study design: study 1}

BUD (200 and $800 \mu \mathrm{g})$, FP (200 and $800 \mu \mathrm{g}$ ), and placebo were administered as an aqueous nasal spray (Rhinocort $50 \mu \mathrm{g}$ per puff, and Flixonase $50 \mu \mathrm{g}$ per puff) divided over both nostrils. BUD $(1600 \mu \mathrm{g})$ and FP $(1500 \mu \mathrm{g})$ were inhaled into the lungs in random order. The drugs were administered once as a single dose with an interval of at least 1 week between the administrations. All medications were supplied by the hospital pharmacy in the package normally delivered by the supplier. The placebo was a Rhinocort aqueous nasal spray placebo kindly donated by Astra Holland. The drugs were supplied to the volunteers by a doctor and taken in his presence. The blood samples were given a code and sent to the investigators in a blinded way. The $800 \mu \mathrm{g}$ of aqueous nasal 
Total lymphocytes $* 10^{9} / 1$

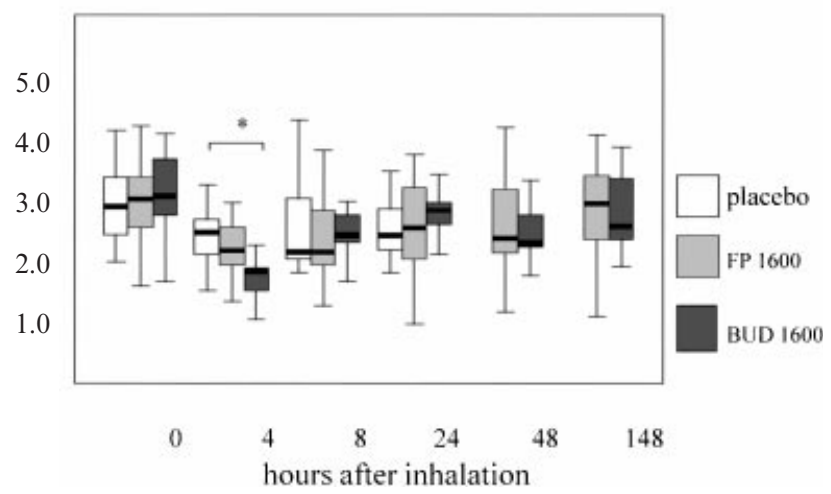

Figure 2. Box plots of changes in midstream total lymphocyte count after inhalation of budesonide $1600 \mu \mathrm{g}$, fluticasone propionate $1600 \mu \mathrm{g}$, or placebo in lung of healthy volunteers at different time points after inhalation. ${ }^{\star}$ Significant reduction $(P=0.002)$.

spray was administered as four series of $200 \mu \mathrm{g}$ with $15-30 \mathrm{~s}$ between the series to prevent overwetting of the nose. The bronchial medication was administered by metered-dose inhaler, $6 \times 250 \mu \mathrm{g}$ for FP, and $4 \times 400 \mu \mathrm{g}$ for BUD. The mouth was not rinsed after the bronchial inhalation.

A blood sample was taken of all volunteers between 8 and 9 a.m. The fresh blood samples were blinded and taken to the laboratory directly, and total lymphocyte count and different subpopulations were determined. A second blood sample was taken $4 \mathrm{~h}$ later. The handling of this sample was the same as for the first sample.

\section{Volunteers: study 2}

For further elucidation of the findings in study 1 , a second study was performed to check for reproducibility of the assay and diurnal variation. A double-blind, double-dummy, crossover study was performed to compare BUD $1600 \mu \mathrm{g}$, FP $1600 \mu \mathrm{g}$, and placebo at four time points during the day after inhalation and (for the active medication) also after $48 \mathrm{~h}$ and 7 days.

Fifteen healthy volunteers, median age 23 years (range 1931), seven women, eight men, participated in this study. None of the volunteers were taking any medication. None of the volunteers had a history of rhinitis or asthma symptoms. All volunteers had normal lung function.

\section{Study design: study 2}

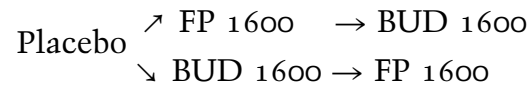

Placebo was inhaled at visit o (after the first blood sample), and blood samples were taken at $0,4,8$, and $24 \mathrm{~h}$ after the inhalation. Volunteers were than randomized to either BUD $(1600 \mu \mathrm{g})$ or FP $(1600 \mu \mathrm{g})$ inhaled into the lungs. The drugs were administered once as a single dose, with a 1 -week interval between the administrations. The bronchial medication was administered via Diskus ${ }^{\mathrm{TM}}$ inhaler $3 \times 500 \mu \mathrm{g}$ and $1 \times 100 \mu \mathrm{g}$ for FP, and via Turbuhaler ${ }^{\mathrm{TM}}$ inhaler

Table 1B. Total lymphocytes and subpopulations after application of local corticosteroid spray in lung

\begin{tabular}{|c|c|c|c|c|c|c|c|}
\hline & Application & $\begin{array}{l}0 \\
\text { Median } \\
\text { (range) }\end{array}$ & $\begin{array}{l}4 \\
\text { Median } \\
\text { (range) }\end{array}$ & $\begin{array}{l}8 \\
\text { Median } \\
\text { (range) }\end{array}$ & $\begin{array}{l}24 \\
\text { Median } \\
\text { (range) }\end{array}$ & $\begin{array}{l}48 \\
\text { Median } \\
\text { (range) }\end{array}$ & $\begin{array}{l}148 \\
\text { Median } \\
\text { (range) }\end{array}$ \\
\hline \multirow[t]{3}{*}{ Total lymphocytes } & Placebo & $2.9(2.0-4.1)$ & $2.5(1.5-3.2)$ & $2.1(1.8-4.3)$ & $2.4(1.8-3.5)$ & & \\
\hline & FP & $3.0(1.6-4.2)$ & $2.1(1.0-2.9)$ & $2.4(1.3-38)$ & $2.5(1.0-5.2)$ & $2.3(1.2-4.2)$ & $3.0(1.1-4.1)$ \\
\hline & BUD & $3.1(1.7-4.1)$ & $1.8(1.0-2.6)^{*}$ & $2.6(1.7-3.5)$ & $2.8(2.1-3.5)$ & $2.4(1.8-4.7)$ & $2.6(1.9-3.9)$ \\
\hline \multirow[t]{3}{*}{ CD4+ cells } & Placebo & $1.2(0.8-2.0)$ & $0.8(0.6-1.7)$ & $1.1(0.6-2.3)$ & $1.0(0.6-1.7)$ & & \\
\hline & FP & $1.4(0.7-2.2)$ & $0.9(0.3-1.2)$ & $0.9(0.5-2.0)$ & $1.1(0.4-2.4)$ & $1.1(0.5-2.2)$ & $1.3(0.4-2.1)$ \\
\hline & BUD & $1.3(0.8-2.1)$ & $0.6(0.4-1.1)^{*}$ & $1.0(0.5-1.4)$ & $1.3(0.9-1.8)$ & $1.1(0.6-2.4)$ & $1.1(0.7-1.8)$ \\
\hline \multirow[t]{3}{*}{ CD8+ cells } & Placebo & $0.6(0.4-1.2)$ & $0.5(0.3-0.7)$ & $0.5(0.3-0.9)$ & $0.6(0.4-1.0)$ & & \\
\hline & FP & $0.7(0.3-1.0)$ & $0.5(0.2-0.7)$ & $0.5(0.3-0.9)$ & $0.6(0.2-0.8)$ & $0.6(0.2-0.8)$ & $0.7(0.2-0.9)$ \\
\hline & BUD & $0.7(0.5-1.1)$ & $0.4(0.2-0.7)^{*}$ & $0.6(0.4-0.8)$ & $0.7(0.5-1.2)$ & $0.6(0.4-0.9)$ & $0.7(0.5-1.1)$ \\
\hline \multirow[t]{3}{*}{ B cells } & Placebo & $0.5(0.2-0.7)$ & $0.4(0.1-0.5)$ & $0.4(0.2-0.5)$ & $0.4(0.2-0.6)$ & & \\
\hline & FP & $0.4(0.1-0.7)$ & $0.3(0.1-0.5)$ & $0.4(0.2-0.6)$ & $0.4(0.2-0.6)$ & $0.3(0.1-0.7)$ & $0.4(0.2-0.6)$ \\
\hline & BUD & $0.4(0.2-0.7)$ & $0.2(0.1-0.4)^{*}$ & $0.3(0.1-0.7)$ & $0.3(0.2-0.7)$ & $0.3(0.1-0.5)$ & $0.4(0.2-0.6)$ \\
\hline \multicolumn{8}{|c|}{$\begin{array}{l}\text { Budesonide } 1600 \mu \mathrm{g} \text { and fluticasone propionate } 1600 \mu \mathrm{g} \text { were inhaled into lungs. Total number of lymphocytes showed significant } \\
\text { reduction } 4 \mathrm{~h} \text { after application of budesonide } 1600 \mu \mathrm{g}(P=0.002) \text { compared to placebo. Significant reduction was also found } 4 \mathrm{~h} \text { after } \\
\text { inhalation of budesonide } 1600 \mu \mathrm{g} \text { compared to placebo in CD4+(P=0.001) and CD8+fractions }(P=0.009) \text { of T cells and total number of } \\
\text { B cells }(P=0.002) \text {. No significant differences were found at other time points. Nor were significant differences found after inhalation } \\
\text { of fluticasone propionate } 1600 \mu \mathrm{g} \text {. } \\
{ }^{*} P \text { value active treatment vs placebo }<0.01 \text {. }\end{array}$} \\
\hline
\end{tabular}


$4 \times 400 \mu \mathrm{g}$ for BUD. The mouth was not rinsed after the bronchial inhalation. The drugs were supplied to the volunteers by a doctor and taken in his presence. Active medication and placebo were kindly supplied by Glaxo Wellcome Holland. The blood samples were given a code and sent to the investigators in a blinded way.

A blood sample was taken from all volunteers between 8 and 9 a.m before randomization. The fresh blood samples were blinded and taken to the laboratory directly, and total lymphocyte count and different subpopulations were determined. Further blood samples were taken 4, 8, 24, 48, and $148 \mathrm{~h} \mathrm{(=7} \mathrm{days)} \mathrm{after} \mathrm{inhalation} \mathrm{of} \mathrm{the} \mathrm{medication.} \mathrm{The}$ handling of these samples was the same as for the first sample.

\section{Lymphocyte subpopulation enumeration}

Heparinized peripheral blood (PB) samples were obtained from subjects and analyzed the same day. Analyses were performed with a FAC-Scan flow cytometer (Becton Dickinson, San Jose, CA, USA). Whole blood was incubated with a panel of optimally titrated fluorescein isothiocyanate (FITC)- or phycoerythrin (PE)-conjugated monoclonal antibodies (mAbs) for single or double immunofluorescence staining. As a rule, irrelevant IgG2 FITC- or IgG1 PEconjugated $\mathrm{mAbs}$ were used as negative controls. Before flow cytometric analysis, red blood cells were lysed with FACS lysing solution (Becton Dickinson).

The mAbs used in this study, obtained from Becton Dickinson unless mentioned otherwise, were as follows: CD19 (Leu-12 PE) and CD2o (B1 FITC; Coulter Clone, Hialeah, FL, USA) to label B cells; $\mathrm{CD}_{3}$ (Leu-4 FITC), CD4 (Leu-3 FITC or Leu-3 PE), and CD8 (Leu-2 PE) to label T cells; CD5 (Leu-1 FITC) to label T and B cells; CD16 (Leu11c PE) and $\mathrm{CD}_{5} 6$ (Leu-19 PE) to label natural killer (NK) cells; anti-HLA-DR (L243 PE) to label activated T cells; and CD14 (My4 PE; Coulter Clone) and CD45 (HLe-1 FITC) to determine, in combination with the whole-blood forward and side-scatter patterns, the percentages of granulocytes, monocytes, and lymphocytes (Leucogate). Further data analyses were made of the lymphocyte population thus defined. This lymphocyte population represented at least $95 \%$ of the total number of lymphocytes and contained less than $3 \%$ contamination by monocytes. White blood cells were counted with a Coulter Counter Model ZM (Coulter Electronics, Hialeah, FL, USA). Thus, absolute numbers of the following lymphocyte (sub)populations were determined: B cells $\left(\mathrm{CD}_{1} 9^{+}\right.$and/or $\left.\mathrm{CD}_{2} \mathrm{O}^{+}\right), \mathrm{CD}_{5}{ }^{+} \mathrm{B}$ cells $\left(\mathrm{CD}_{5}{ }^{+}\right.$, $\left.\mathrm{CD}_{19}{ }^{+}\right), \mathrm{CD}_{4}{ }^{+} \mathrm{T}$ cells $\left(\mathrm{CD}_{4}{ }^{+}, \mathrm{CD}_{3}{ }^{+}\right), \mathrm{CD} 8^{+} \mathrm{T}$ cells $\left(\mathrm{CD} 8^{+}\right.$,
$\left.\mathrm{CD}_{3}{ }^{+}\right)$, activated $\mathrm{T}$ cells $\left(\mathrm{HLA}-\mathrm{DR}^{+}, \mathrm{CD}_{3}{ }^{+}\right)$, and NK cells $\left.\left(\mathrm{CD}_{1} 6^{+} \text {and/or } \mathrm{CD}_{5} 6^{+}, \mathrm{CD}_{3}\right)^{-}\right)(11)$.

\section{Statistical analysis}

Data were analyzed by the SPSS for Windows 6.1 package. Data were described with box plots (median, 25th, and 75th percentiles, the smallest (largest) value not more than 1.5 box lengths from the 25 th $\left(75^{\text {th }}\right.$ ) percentile. Measurements between baseline and $4 \mathrm{~h}$ in study 1 were analyzed by the nonparametric paired Mann-Whitney U test. In study 2, carry-over effects were measured by comparing the sums of the two randomization groups. Differences between treatments and placebo at different time points were analyzed by the nonparametric paired Mann-Whitney $U$ test. To compensate for multiple testing, a $P$ value smaller than o.01 was called significant.

\section{Results}

\section{Study 1}

Box plots for the total number of lymphocytes, and number of B cells and CD4+ and CD8+ lymphocytes at baseline and after $4 \mathrm{~h}$ for the different treatments are shown in Fig. 1. For the total number of lymphocytes, a significant reduction was found only after inhalation of BUD $1600 \mu \mathrm{g}(P=0.02)$. A significant reduction was also found in the total number of $\mathrm{T}$ cells $(P=0.02)$, the $\mathrm{CD}_{4}+(P=0.02)$ and the CD8+ fractions $(P=0.01)$, and the total number of $\mathrm{B}$ cells $(P=0.03)$ after inhalation of BUD $1600 \mu \mathrm{g}$ (Fig. 1b). No significant differences were found between the parameters with any other application. Nor was a significant reduction found in the percentages of various lymphocyte subpopulations (Table 1A) compared to the total number of lymphocytes.

However, large individual differences were found. After inhalation of BUD $1600 \mu \mathrm{g}$, three subjects had a reduction of total lymphocyte count of more than $40 \%$, while one patient did not have any reduction. After inhalation of FP $1500 \mu \mathrm{g}$, the largest reduction was $22 \%$. Three subjects did not have a reduction. No significant correlation was found between the reduction after BUD $1600 \mu \mathrm{g}$ and the reduction after FP 1500 $\mu \mathrm{g}(r=0.23)$.

\section{Study 2}

For further elucidation of the findings in study 1 , a second study was performed to check for reproducibility of the assay and 
diurnal variation. A double-blind, double-dummy, crossover study was performed to compare BUD $1600 \mu \mathrm{g}, \mathrm{FP} 1600 \mu \mathrm{g}$, and placebo at four time points during the day after inhalation and (for the active medication) also after $48 \mathrm{~h}$ and 7 days.

No significant carry-over effects were found between the two randomization groups. Because no carry-over effects were found, the data from the two randomization groups were evaluated together.

Box plots for the total number of lymphocytes at baseline and after 4, 8, 24, 48, and $148 \mathrm{~h}$ (=7 days) for the different treatments are shown in Fig. 2. For the total number of lymphocytes, a significant reduction of $38 \%$ (range 7-63\%) was found $4 \mathrm{~h}$ after inhalation of BUD $1600 \mu \mathrm{g}$ compared to placebo $(P=0.002)$. A significant reduction was also found $4 \mathrm{~h}$ after inhalation of BUD $1600 \mu \mathrm{g}$ compared to placebo in the total number of $\mathrm{T}$ cells $(P=0.002)$, the $\mathrm{CD}_{4}+(P=0.001)$ and the CD8+ fractions $(P=0.009)$, and the total number of $\mathrm{B}$ cells $(P=0.002)$ (Table $1 \mathrm{~B})$. No significant differences were found at other time points. Nor were significant differences found after inhalation of FP $1600 \mu \mathrm{g}$ (Table $1 \mathrm{~B}$ ). Although marked differences were found between subjects who responded to corticosteroids and those who hardly responded, no significant correlation was found between the reduction after BUD $1600 \mu \mathrm{g}$ and that after FP $1600 \mu \mathrm{g}$.

\section{Discussion}

Systemic corticosteroids induce lymphopenia and eosinopenia (8). Studies examining the effect of local corticosteroid treatment in the nose and lung have shown variable results $(6,7,9,10)$.

None of the applications of the aqueous nasal sprays up to $800 \mu \mathrm{g}$ resulted in a reduction of lymphocytes. This is in contrast to the results of Wihl et al., who, in a study comparing BUD and beclomethasone dipropionate aqueous nasal spray, showed a significant decrease in urine cortisol after BUD 400 and $800 \mu$ g. However, Wihl et al. selected their healthy volunteers by steroid sensitivity (6). On the other hand, overnight urine cortisol, although more cumbersome, may be more sensitive than the method used in the present study. Moreover, Wihl et al. introduced the $800 \mu \mathrm{g}$ of aqueous nasal spray in $4 \mathrm{~min}$, compared to $1-2 \mathrm{~min}$ in this study.
Although no obvious spill of spray was seen, reduced bioavailability due to overwetting of the nose $(0.8 \mathrm{ml})$ cannot be excluded. The results of this study also contradict the suggestion of Mygind et al. (12) that ""a dose of a steroid sprayed in the nose will have more systemic activity than when inhaled. More of the drug reaches the absorbing, airway mucosa in the nose $(20-50 \%)$ than when delivered to the lower airways (10-20\%)." Possibly, the nasal mucosa is better protected against systemic absorption than the bronchial mucosa by the mucus layer and/or the mucociliary clearance.

In both studies, bronchial inhalation of BUD $1600 \mu \mathrm{g}$ as a single dose produced a significant reduction compared to placebo in total lymphocyte count and in the T-cell subfractions in healthy volunteers after $4 \mathrm{~h}$. Comparison with placebo was done to exclude effects due to normal diurnal variation. The magnitude and time span of the effect of BUD $1600 \mu \mathrm{g}$ indicates that marginalization is the main mechanism responsible for our findings because other possible mechanisms such as migration of lymphocytes to the tissues or decreased release from the bone marrow are not likely to occur within $4 \mathrm{~h}$. No significant differences in cell counts were found after bronchial inhalation of FP in nominally the same dose, at any time point. This is in contrast with other studies in healthy volunteers that used measurements of the HPA axis, which usually indicate that the systemic potency of FP is higher than that of BUD (7). It was noteworthy that after the bronchial inhalation of BUD $1600 \mu \mathrm{g}$, some volunteers responded with decreases in total lymphocyte count of over $40 \%$, whereas others did not respond at all. This might indicate varying susceptibility. Further studies are needed to determine whether the method used in this study could serve to evaluate steroid susceptibility.

It is not clear whether the results obtained in this study in healthy volunteers will also be found in the diseased mucosa normally seen in rhinitis and asthma. Moreover, it is not clear how long the reduction of lymphocytes after daily inhalation of BUD $1600 \mu \mathrm{g}$ will persist, nor whether it has any clinical significance or is correlated with (other) adverse effects such as growth inhibition or osteoporosis. Further studies are in progress to answer these questions. For now, this "'marginalization test" might be a promising tool to study the systemic availability of locally administered corticosteroids.

\section{References}

1. Fokkens W, Godthelp T, Holm AF, Blom H, KleinJan A. Allergic rhinitis and inflammation: the effect of nasal corticosteroid therapy. Allergy 1997;52

Suppl 36:29-32.
2. Lipworth BJ. Clinical pharmacology of corticosteroids in bronchial asthma. Pharmacol Ther 1993;58:173-209.
3. Jacobs M. Maintenance therapy for obstructive lung disease. How to achieve the best response with the fewest agents. Postgrad Med 1994;95:87-90,93-96,99. 
4. Hanania NA, Chapman KR, Kesten S. Adverse effects of inhaled corticosteroids [Review]. Am J Med 1995;98:196-208.

5. Boorsma M, Andersson N, Larsson P, Ullman A. Assessment of the relative systemic potency of inhaled fluticasone and budesonide. Eur Respir J 1996;9:1427-1432.

6. Wihl J-Å, Andersson K-E, Johansson S-Å. Systemic effects of two nasally administered glucocorticosteroids. Allergy 1997;52:620626
7. Pederson S, O'Byrne P. A comparison of the efficacy and safety of inhaled corticosteroids in asthma. Allergy 1997;52 Suppl 39:1-34.

8. Fauci A, Dale D, Balow J. Glucocorticosteroid therapy: mechanisms of action and clinical considerations. Ann Intern Med 1976;84:304315 .

9. Blaiss MS, Herrod HG, Crawford LV, Lieberman PL. Beclomethasone dipropionate aerosol: hematologic and immunologic effects. Ann Allergy 1982;48:2 10-214.
10. Evans PM, O'Connor BJ, Fuller RW, Barnes PJ, Chung KF. Effect of inhaled corticosteroids on peripheral blood eosinophil counts and density profiles in asthma.

J Allergy Clin Immunol 1993;91:643-650.

11. van de Merwe JP, van den Beemd MW, Hooijkaas H. $\mathrm{CD}_{5}+\mathrm{B}$ lymphocytes and other lymphocyte subsets in primary Sjögren's syndrome. Neth J Med 1992;40:158-164.

12. Mygind N, Dahl R, Pedersen S, ThestrupPedersen K. Essential allergy. 2nd ed. Oxford: Blackwell, 1996. 